\title{
ESI-FTICR-MS Studies on Gas Phase Fragmentation Reactions of $\mathrm{ArPd}\left(\mathrm{PPh}_{3}\right)_{2} \mathrm{I}$ Complexes
}

\author{
Rong Qian, Yuan-Xi Liao, and Yin-Long Guo \\ Shanghai Mass Spectrometry Center, Shanghai Institute of Organic Chemistry, Chinese Academy of Sciences, \\ Shanghai, People's Republic of China
}

\author{
Hao Guo \\ State Key Laboratory of Organometallic Chemistry, Shanghai Institute of Organic Chemistry, Chinese \\ Academy of Sciences, Shanghai, People's Republic of China
}

\begin{abstract}
Gas-phase fragmentation reactions of $\left[\mathrm{ArPd}\left(\mathrm{PPh}_{3}\right)_{2}\right]^{+}$were studied by electrospray ionization Fourier transform ion cyclotron resonance mass spectrometry (ESI-FTICR-MS). The results of sustained off-resonance irradiation collision-activated dissociation (SORI-CAD) experiments provide detailed insights into mechanisms for the gas-phase fragmentation reactions of these complex ions. The $\mathrm{P}-\mathrm{C}$ bond cleavage mediated by palladium is investigated in the gas phase. There are two competitive fragmentation pathways for the complex ions $\left[\mathrm{ArPd}\left(\mathrm{PPh}_{3}\right)_{2}\right]^{+}(\mathrm{Ar}$ $=p-\mathrm{OCH}_{3}-\mathrm{C}_{6} \mathrm{H}_{4}, p-\mathrm{CH}_{3}-\mathrm{C}_{6} \mathrm{H}_{4}, p-t \mathrm{Bu}-\mathrm{C}_{6} \mathrm{H}_{4}, p-\mathrm{NH}_{2}-\mathrm{C}_{6} \mathrm{H}_{4}, p-\mathrm{COCH}_{3}-\mathrm{C}_{6} \mathrm{H}_{4}$, and $p-\mathrm{F}-\mathrm{C}_{6} \mathrm{H}_{4}$ ) of electron-donating and electron-withdrawing aromatic iodides. Path A proceeds through reductive elimination of $\left[\mathrm{ArPd}\left(\mathrm{PPh}_{3}\right)_{2}\right]^{+}$to produce the product ion $\left[\mathrm{PPh}_{3} \mathrm{Ar}\right]^{+}$. Path $\mathrm{B}$ mostly proceeds via phenyl migration from the triphenylphosphine ligand to the palladium center by cleavage of the phosphorus - phenyl bond to give a palladium - phenyl intermediate, and subsequent reductive elimination of the intermediate to yield a product ion $\left[\mathrm{PPh}_{4}\right]^{+}$. The result of deuterium-labeling experiments provides evidence for the phenyl shift between the palladium center and the coordinated ligand through cleavage of the $\mathrm{P}-\mathrm{C}$ bond. The complex ions $\left[\left(o-\mathrm{CH}_{3}-\mathrm{C}_{6} \mathrm{H}_{4}\right) \mathrm{Pd}\left(\mathrm{PPh}_{3}\right)_{2}\right]^{+},\left[\left(o-2,6-\mathrm{Me}_{2}-\mathrm{C}_{6} \mathrm{H}_{3}\right) \mathrm{Pd}\left(\mathrm{PPh}_{3}\right)_{2}\right]^{+}$, and $\left[\left(\mathrm{C}_{10} \mathrm{H}_{7}\right) \mathrm{Pd}\left(\mathrm{PPh}_{3}\right)_{2}\right]^{+}$display more fragmentation pathways, two of which are similar to those of the ions [ArPd$\left.\left(\mathrm{PPh}_{3}\right)_{2}\right]^{+}\left(\mathrm{Ar}=p-\mathrm{OCH}_{3}-\mathrm{C}_{6} \mathrm{H}_{4}, p-\mathrm{CH}_{3}-\mathrm{C}_{6} \mathrm{H}_{4}, p-t \mathrm{Bu}-\mathrm{C}_{6} \mathrm{H}_{4}, p-\mathrm{NH}_{2}-\mathrm{C}_{6} \mathrm{H}_{4}, p-\mathrm{COCH}_{3}-\mathrm{C}_{6} \mathrm{H}_{4}, p-\mathrm{F}-\right.$ $\left.\mathrm{C}_{6} \mathrm{H}_{4}\right)$, and the third pathway involves loss of one molecule of benzene and one $\mathrm{PPh}_{3}$ ligand. The electronic effect and steric effect of the aryl groups also exhibit different influences on the fragmentation pathways. (J Am Soc Mass Spectrom 2006, 17, 1582-1589) (c) 2006 American Society for Mass Spectrometry
\end{abstract}

$\mathrm{O}$ rganopalladium complexes $\left[\operatorname{ArPd}\left(\mathrm{R}_{3} \mathrm{P}\right)_{2} \mathrm{X}\right](\mathrm{X}=$ halogen) play important roles as key intermediates in numerous Pd-catalyzed reactions of aryl halides, such as the Heck arylation of olefins, the Kharasch-Fields, Stille, Suzuki, and Sonogashira coupling reactions, and many nucleophilic displacement and carbonylation reactions [1-6]. These complexes provide an attractive point into various $\mathrm{Pd}$-catalyzed cross-couplings, due to both enhanced catalytic activity relative to zerovalent $\mathrm{PdL}_{\mathrm{n}}$ complexes and ease of handling. However, the aryl-aryl interchange reaction of $\left[\operatorname{ArPd}\left(\mathrm{R}_{3} \mathrm{P}\right)_{2} \mathrm{X}\right]$ usually resulted in the formation of phosphine-derived by-products in catalytic and stoichi-

Published online August 9, 2006

Address reprint requests to Dr. Y.-L. Guo, Shanghai Mass Spectrometry Center, Shanghai Institute of Organic Chemistry, Chinese Academy of Sciences, Shanghai 200032, P.R., China. E-mail: ylguo@mail.sioc.ac.cn ometric cross-coupling reactions, which has been investigated by Cheng, Novak, and Grushin etc. [7-12]. In addition, many methods have been developed to prevent the aryl-aryl interchange reaction and reduce the limitations of the catalytic chemistry of aromatic halides $[13,14]$.

It was also recognized that tertiary phosphine-metal complexes are chemically reactive and susceptible to carbon-phosphorus bond scission depending on the specific reaction conditions [15]. Many results concerning carbon-phosphorus bond activation by transitionmetal complexes have been reported, most of which included aryl carbon-phosphorus bond cleavage in triarylphosphines [15-19]. There are two mechanisms that have been proposed for migration of aryl from phosphine toward the metal: a shift of aryl from the metal-bonded phosphine or an oxidative addition of arylphosphine [17]. Although examples of transition- 


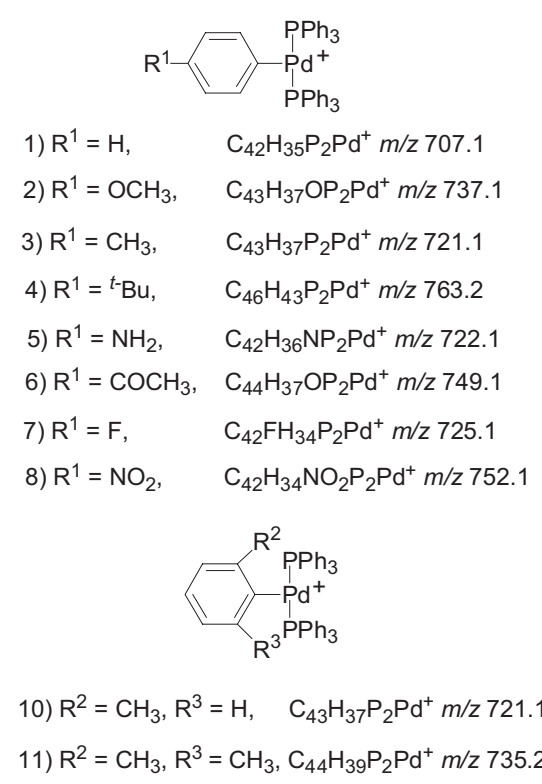

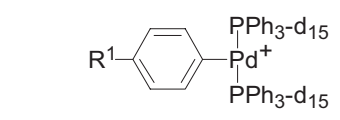

9) $\mathrm{R}^{1}=\mathrm{OCH}_{3}, \mathrm{C}_{43} \mathrm{H}_{7} \mathrm{D}_{30} \mathrm{OP}_{2} \mathrm{Pd}^{+} \mathrm{m} / \mathrm{z} 767.1$

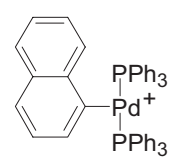

12) $\mathrm{C}_{46} \mathrm{H}_{37} \mathrm{P}_{2} \mathrm{Pd}^{+} m / z 757.1$

Scheme 1. Structures of organopalladium complex ions studied by ESI-FTICR-MS.

metal complexes activating the carbon-phosphorus bond remain to be exploited, reaction of the phosphorus - carbon bond with the transition-metal to which the tertiary phosphine is bound has profound implications for homogeneous catalysis [15, 18, 19].

Recently, electrospray ionization mass spectrometry (ESI-MS) has been used extensively for structural characterization of metal containing compounds and mechanism determination of some gas-phase reactions, combined with tandem mass spectrometric (MS/MS) methods involving collision-activated dissociation (CAD) [20-26]. Previously, we have used electrospray ionization Fourier transform ion cyclotron resonance mass spectrometry (ESI-FTICR-MS) to provide insight into the mechanism of $\mathrm{Pd}(0)$-catalyzed threecomponent tandem double addition-cyclization, and successfully characterized some key intermediates, which confirmed the proposed mechanism for the reaction [27]. During this preliminary work, an interesting gas-phase fragmentation reaction of $\left[\mathrm{PhPd}\left(\mathrm{PPh}_{3}\right)_{2}\right]^{+}$ was observed. In a sustained off-resonance irradiation collision-activated dissociation (SORI-CAD) experiment, the precursor ion $\left[\mathrm{PhPd}\left(\mathrm{PPh}_{3}\right)_{2}\right]^{+}$fragmented to yield a product ion $\left[\mathrm{PPh}_{4}\right]^{+}[27-29]$. The specific interest here is to demonstrate the gas-phase behavior of these analogous complexes by mass spectrometry, and to find the origins of phenyl in $\left[\mathrm{PPh}_{4}\right]^{+}$dissociated from the precursor ion $\left[\mathrm{PhPd}\left(\mathrm{PPh}_{3}\right)_{2}\right]^{+}$. Because the complex ion $\left[\mathrm{ArPd}\left(\mathrm{PPh}_{3}\right)_{2}\right]^{+}$and the aryl-aryl interchange product ion $\left[\mathrm{PhPd}\left(\mathrm{PPh}_{3}\right)\left(\mathrm{PPh}_{2} \mathrm{Ar}\right)\right]^{+}$are isomers and cannot be distinguished by ESI-FTICR-MS, the aryl-aryl interchange reaction should be inhibited in the process of preparing $\mathrm{ArPd}\left(\mathrm{PPh}_{3}\right)_{2} \mathrm{I}$ or in the mass spectrometric analysis process.

In this paper, gas-phase fragmentation reactions of a series of organopalladium complexes $\operatorname{ArPd}\left(\mathrm{PPh}_{3}\right)_{2} \mathrm{I}$ are studied. The general formula for the coordinated organopalladium ions and a description of the aromatic iodides are given in Scheme 1 Their elemental compositions are confirmed through accurate mass measurement data, and their fragmentation pathways are studied by SORI-CAD experiments and deuterium labeling experiments. In addition to the fragmentation pathways for these organopalladium ions, the influence of the electronic effect and steric effect of the functional groups in aromatic halides on the fragmentation reactions will also be presented.

\section{Experimental}

\section{Materials and Sample Preparation}

The starting materials, tetrakis(triphenylphosphine)palladium $\left(\mathrm{Pd}\left(\mathrm{PPh}_{3}\right)_{4}\right)$, tri $\left(\right.$ phenyl- $\left.\mathrm{d}_{15}\right)$ phosphine $\left(\mathrm{PPh}_{3}-\mathrm{d}_{15}\right)$, and all the aromatic iodides, were purchased from SigmaAldrich Co. (St. Louis, MO). The tetrahydrofuran (THF) and $\mathrm{CH}_{3} \mathrm{CN}$ were HPLC-grade solvents from Merck Co. (Darmstadt, Germany). The complexes $\operatorname{ArPd}\left(\mathrm{PPh}_{3}\right)_{2} \mathrm{I}$ were prepared by stirring a solution of ArI $(0.005 \mathrm{mmol})$ and $\mathrm{Pd}\left(\mathrm{PPh}_{3}\right)_{4}(0.005 \mathrm{mmol})$ in THF $(6 \mathrm{~mL})$ at room temperature under an atmosphere of nitrogen [30]. The deuterated complex $\left(p-\mathrm{OCH}_{3}-\mathrm{C}_{6} \mathrm{H}_{4}\right) \mathrm{Pd}\left(\mathrm{PPh}_{3}-\mathrm{d}_{15}\right)_{2} \mathrm{I}$ was prepared by stirring a solution of $p-\mathrm{OCH}_{3}-\mathrm{C}_{6} \mathrm{H}_{4} \mathrm{I}(0.005 \mathrm{mmol})$ and $\mathrm{Pd}\left(\mathrm{PPh}_{3}-\mathrm{d}_{15}\right)_{4}(0.005 \mathrm{mmol})$ in THF $(6 \mathrm{~mL})$ at room temperature under an atmosphere of nitrogen. The $\mathrm{Pd}\left(\mathrm{PPh}_{3}-\mathrm{d}_{15}\right)_{4}$ was prepared as described in the literature [31].

\section{Instrumentation}

The experiments were performed in positive ion mode on a Bruker Daltonics APEX III ESI-FTICR mass spec- 
Table 1. Relative intensities of main product ions of complex ions $\mathbf{1}$ to $\mathbf{8}$, and the ratio of intensities of product ions [PPh $]^{+}$ and $\left[\mathrm{PPh}_{3} \mathrm{Ar}\right]^{+}$

\begin{tabular}{|c|c|c|c|}
\hline Ions & Ions elemental composition & $\begin{array}{c}\text { Relative intensity } \\
\text { of the product ions (\%) }\end{array}$ & $\mathrm{I}\left(\left[\mathrm{PPh}_{4}\right]^{+}\right) / \mathrm{I}\left(\left[\mathrm{PPh}_{3} \mathrm{Ar}\right]^{+}\right)$ \\
\hline \multirow[t]{2}{*}{1} & $\mathrm{C}_{42} \mathrm{H}_{35} \mathrm{P}_{2} \mathrm{Pd}^{+}$ & & a \\
\hline & $\begin{array}{l}\mathrm{C}_{24} \mathrm{H}_{20} \mathrm{P}^{+} \\
\mathrm{C}_{43} \mathrm{H}_{37} \mathrm{OP}_{2} \mathrm{Pd}^{+}\end{array}$ & 85.7 & \\
\hline 2 & $\begin{array}{l}\mathrm{C}_{24} \mathrm{H}_{20} \mathrm{P}^{+} \\
\mathrm{C}_{25} \mathrm{H}_{22} \mathrm{OP}^{+} \\
\mathrm{C}_{43} \mathrm{H}_{37} \mathrm{P}_{2} \mathrm{Pd}^{+}\end{array}$ & $\begin{array}{r}5.1 \\
96.2\end{array}$ & 0.053 \\
\hline 3 & $\begin{array}{l}\mathrm{C}_{24} \mathrm{H}_{20} \mathrm{P}^{+} \\
\mathrm{C}_{25} \mathrm{H}_{22} \mathrm{P}^{+} \\
\mathrm{C}_{46} \mathrm{H}_{43} \mathrm{P}_{2} \mathrm{Pd}^{+}\end{array}$ & $\begin{array}{r}7.8 \\
48.8\end{array}$ & 0.16 \\
\hline 4 & $\begin{array}{l}\mathrm{C}_{24} \mathrm{H}_{20} \mathrm{P}^{+} \\
\mathrm{C}_{28} \mathrm{H}_{28} \mathrm{P}^{+} \\
\mathrm{C}_{42} \mathrm{H}_{36} \mathrm{NP}_{2} \mathrm{Pd}^{+}\end{array}$ & $\begin{array}{r}8.5 \\
97.7\end{array}$ & 0.087 \\
\hline 5 & $\begin{array}{l}\mathrm{C}_{24} \mathrm{H}_{20} \mathrm{P}^{+} \\
\mathrm{C}_{24} \mathrm{H}_{21} \mathrm{NP}^{+} \\
\mathrm{C}_{44} \mathrm{H}_{37} \mathrm{OP}_{2} \mathrm{Pd}^{+}\end{array}$ & $\begin{array}{l}13.2 \\
69.5\end{array}$ & 0.19 \\
\hline 6 & $\begin{array}{l}\mathrm{C}_{24} \mathrm{H}_{20} \mathrm{P}^{+} \\
\mathrm{C}_{26} \mathrm{H}_{22} \mathrm{OP}^{+} \\
\mathrm{C}_{42} \mathrm{FH}_{34} \mathrm{P}_{2} \mathrm{Pd}^{+} \mathrm{C}\end{array}$ & $\begin{array}{r}90.2 \\
6.6\end{array}$ & 13.67 \\
\hline 7 & $\begin{array}{l}{ }_{24} \mathrm{H}_{20} \mathrm{P}^{+} \\
\mathrm{C}_{24} \mathrm{FH}_{19} \mathrm{P}^{+}\end{array}$ & $\begin{array}{l}92.4 \\
14.3\end{array}$ & 6.46 \\
\hline 8 & $\begin{array}{l}\mathrm{C}_{42} \mathrm{H}_{34} \mathrm{NO}_{2} \mathrm{P}_{2} \mathrm{Pd}^{+} \\
\mathrm{C}_{24} \mathrm{H}_{20} \mathrm{P}^{+}\end{array}$ & 98.0 & a \\
\hline
\end{tabular}

${ }^{\text {a }}$ The ratio could not be calculated for the single product ion.

trometer (Billerica, MA) equipped with a 7.0 tesla shielded superconducting magnet. The analyses employed an infusion flow rate of $10 \mu \mathrm{L} / \mathrm{min}$, which was maintained by a syringe pump. The basic ESI conditions were: vacuum, $3.7 \times 10^{-7}$ to $2.6 \times 10^{-9}$ torr; CapExit voltage, $52.0 \mathrm{~V}$; offset voltage, $0.9-1.8 \mathrm{~V}$. The ions are accumulated in the RF-only hexapole ion storage region for $1.0 \mathrm{~s}$, focused and steered through the ion transfer region. The other parameters from the ion generation to trapping were optimized on the tuning parameters based on the maximum intensity of parent ion achieved.

In SORI-CAD experiments, the precursor ions of interest were isolated with an isolation sweep attenuation/isolation pulse length of $20 \mathrm{~dB} / 0.8 \mathrm{~ms}$ and then collided with argon gas. The argon collision gas was introduced into the cell through a pulsed valve to maintain a stable pressure. A delay of about $1.0 \mathrm{~s}$ was applied after the parent ion was isolated. During this delay period, no activation pulse was needed and the fragment process was spontaneously generated, which was dependent on the initial kinetic energy of the ions. After the delay period, mass spectra were acquired in the positive ion mode with broadband detection (eight scans per experiment each) from 100 to 1500 Da using $256 \mathrm{~K}$ data points. Therefore, the mass spectra do reflect the dissociation process of the isolated ions. All the experimental sequences, including scan accumulation and data processing, were performed with Bruker Xmass 6.1.2 software. The instrument was calibrated externally with methanol solutions of PEG400 and PEG800.

\section{Results and Discussion}

The structures of the precursor ions and product ions are fully supported by the accurate mass measurements. The relative errors are all less than $5 \mathrm{ppm}$, so the results indicate that the proposed structures have the only reasonable elemental compositions. The comparison of the masses determined, and the actual masses of the proposed structures and the corresponding element compositions of the main fragment ions will be presented.

In general, the gas-phase fragmentation reactions of complex ions 2-7 proceed via two major pathways, while complex ions 10, 11, and $\mathbf{1 2}$ react through three major fragmentation pathways. It should be noted that no aryl-aryl interchange reaction occurs during the mass spectrometric analysis process when the organopalladium ions are isolated in the cell for SORI-CAD experiments by prolonging the pumping delay time for MS/MS from $1.0 \mathrm{~s}$ to $180.0 \mathrm{~s}$. In addition, the electronic and steric effects of the aryl groups exhibit different influences on the observed fragmentation pathways. The details will be discussed below.

Fragmentation of Compounds 1-8: Electronic Effects

Eight complex ions, 1-8, are prepared from aromatic iodides substituted by electron-donating or electronwithdrawing groups in the para position, and studied by ESI-FTICR-MS. The SORI-CAD experiments of the 
precursor ion clusters with the typical palladium isotopic distributions are performed with argon as collision gas. Structures and compositions of precursor ions and fragment ions produced from these complex ions are confirmed by SORI-CAD experiments as shown in Table 1.

The SORI-CAD spectra of these organopalladium ions show that: ion $1\left[(\mathrm{Ph}) \mathrm{Pd}\left(\mathrm{PPh}_{3}\right)_{2}\right]^{+}$at $\mathrm{m} / z 707.1$ yields the product ion $\mathbf{1 A}\left[\mathrm{PPh}_{4}\right]^{+}$at $m / z 339.1$ (Figure $1)$; the other ions 2-7 all give two product ions, $\left[\mathrm{PPh}_{3} \mathrm{Ar}\right]^{+}$and $\mathbf{1 A}$. The product ion $\left[\mathrm{PPh}_{3} \mathrm{Ar}\right]^{+}$is presumably produced mainly from the reductive elimination between the $\mathrm{PPh}_{3}$ ligand and the aryl group bonded to the Pd-atom; the product ion $1 \mathrm{~A}\left[\mathrm{PPh}_{4}\right]^{+}$ resulted from another reductive elimination of a proposed intermediate ion $\left[\mathrm{ArPd}\left(\mathrm{PPh}_{3}\right)(\mathrm{Ph})\left(\mathrm{PPh}_{2}\right)\right]^{+}$, which may be formed via palladium-mediated $\mathrm{P}-\mathrm{C}$ activation and subsequent phenyl migration from the triphenylphosphine ligand to the palladium center [3236]. Ion $1\left[\mathrm{PhPd}\left(\mathrm{PPh}_{3}\right)_{2}\right]^{+}$fragments via these two major pathways to yield only one product ion 1A. However, the ion $8\left[\left(p-\mathrm{NO}_{2} \mathrm{C}_{6} \mathrm{H}_{4}\right) \mathrm{Pd}\left(\mathrm{PPh}_{3}\right)_{2}\right]^{+}$yields only one product ion, 1A. Subsequently, the product ion $1 \mathrm{~A}$ is isolated for MS/MS/MS. Figure 2 shows that $\mathbf{1 A}$ could yield $1 B$ at $m / z 261.1$ and 1 C at $m / z 183.0$ by loss of one molecule of benzene or two molecules of benzene, which further characterizes the structure of the product ion $\mathbf{1 A}$.

It is interesting that the ratio of intensities of product ions $\left[\mathrm{PPh}_{4}\right]^{+}$and $\left[\mathrm{PPh}_{3} \mathrm{Ar}\right]^{+}$dramatically changes when the functional groups of aromatic halides are changed from electron-donating groups to electron-withdrawing groups (Table). It seems that the phenyl migration trend is enhanced by the presence of electron-withdrawing substituents such as the nitro group of ion 8 , and inhibited by the presence of electron-donating substitu-
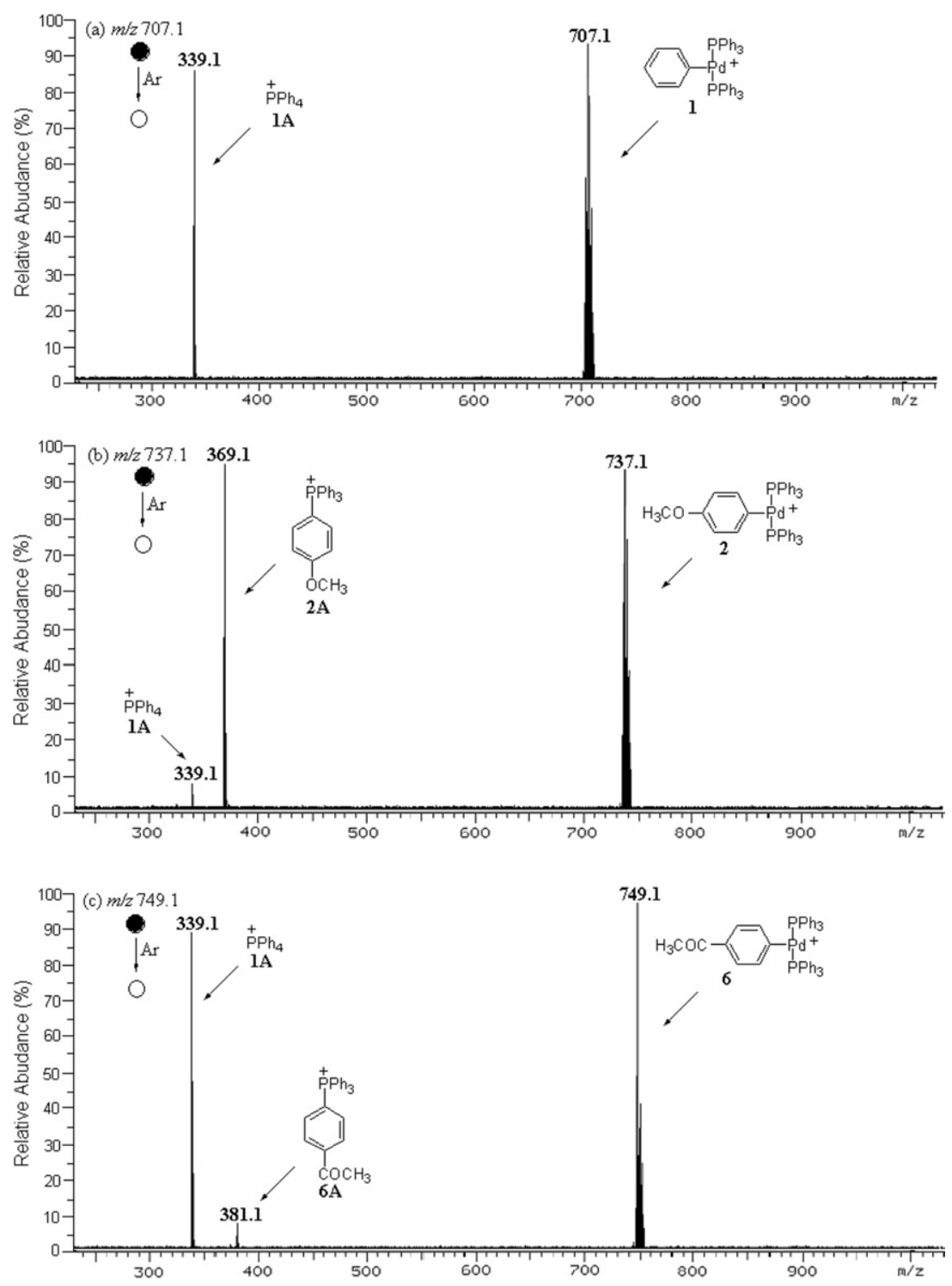

Figure 1. ESI(+)-SORI-CAD spectra for (a) $\left[(\mathrm{Ph}) \mathrm{Pd}\left(\mathrm{PPh}_{3}\right)_{2}\right]^{+},(\mathbf{b})\left[\left(p-\mathrm{OCH}_{3}-\mathrm{C}_{6} \mathrm{H}_{4}\right) \mathrm{Pd}\left(\mathrm{PPh}_{3}\right)_{2}\right]^{+}$, and (c) $\left[\left(p-\mathrm{COCH}_{3}-\mathrm{C}_{6} \mathrm{H}_{4}\right) \mathrm{Pd}\left(\mathrm{PPh}_{3}\right)_{2}\right]^{+}$. 


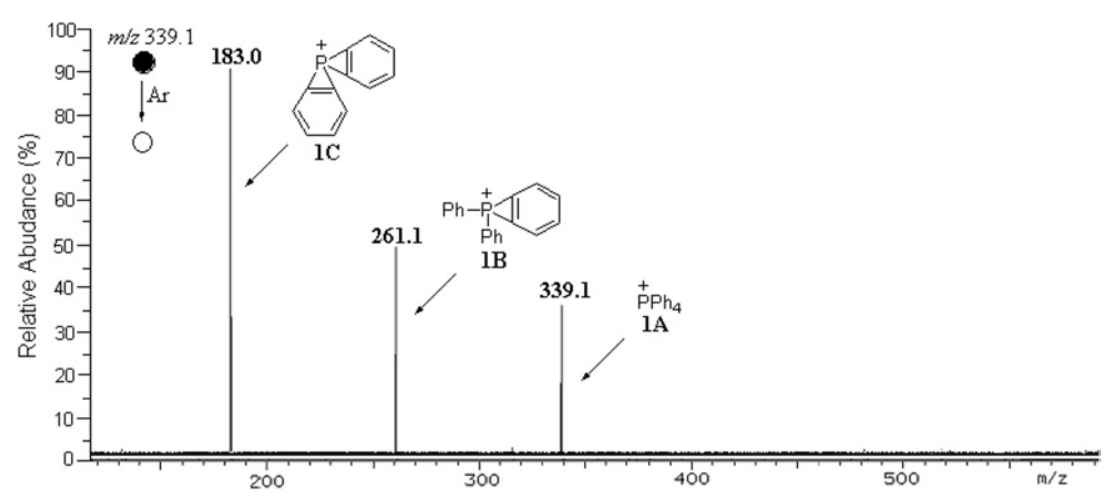

Figure 2. $\mathrm{ESI}(+)-\mathrm{MS} / \mathrm{MS} / \mathrm{MS}$ for the product ion 1A.

ents of aromatic halides. Garrou has investigated substituent effects on the rate of $\mathrm{P}-\mathrm{C}$ bond cleavage; these studies reveal that bond scission is enhanced by electron-withdrawing substituents such as $\mathrm{CF}_{3}$ and inhibited by electron-donating substituents such as OMe of the triarylphosphine ligand in the para position $[15,37$, 38]. Our studies suggest that the influence of substituents of aromatic halides on the $\mathrm{P}-\mathrm{C}$ bond cleavage has some similarity to that from the tertiaryl-phosphine ligand in the para position. Therefore, the fragmentation reaction of ion $8\left[\left(p-\mathrm{NO}_{2}-\mathrm{C}_{6} \mathrm{H}_{4}\right) \mathrm{Pd}\left(\mathrm{PPh}_{3}\right)_{2}\right]^{+}$may be affected by the presence of the strong electron-withdrawing group of $p-\mathrm{NO}_{2}-\mathrm{C}_{6} \mathrm{H}_{4} \mathrm{I}$, which strongly enhances the phenyl migration of ion 8 .

According to the SORI-CAD data, two major mechanisms for the fragmentation reactions of these organopalladium ions are proposed and summarized in Scheme 2. Path A proceeds via reductive elimination of $\left[\mathrm{ArPd}\left(\mathrm{PPh}_{3}\right)_{2}\right]^{+}$to produce the product ion $\left[\mathrm{PPh}_{3} \mathrm{Ar}\right]^{+}$. Path $\mathrm{B}$ mostly proceeds via two steps: first, phenyl migration from triphenylphosphine ligand to the palladium center through cleavage of the $\mathrm{P}-\mathrm{C}$ bond affording a palladium-phenyl intermediate $\left[\mathrm{ArPd}\left(\mathrm{PPh}_{3}\right)(\mathrm{Ph})\left(\mathrm{PPh}_{2}\right)\right]^{+}$; second, reductive elimination of this intermediate to yield the product ion $\left[\mathrm{PPh}_{4}\right]^{+}$and $\left[\mathrm{PPh}_{3} \mathrm{Ar}\right]^{+}$.

\section{Fragmentation of Compound 9: Deuterium}

Labeling Tracing the Phenyl Shift between the Palladium Center and the Coordinated Ligand

To investigate the origin of the phenyl group in $\left[\mathrm{PPh}_{4}\right]^{+}$ eliminated from the complex ions 1 to 8 , a labeling experiment is performed with $\left[\left(\mathrm{C}_{6} \mathrm{H}_{4}-p-\mathrm{OCH}_{3}\right) \mathrm{Pd}\left(\mathrm{PPh}_{3}-\right.\right.$ $\left.\left.\mathrm{d}_{15}\right)_{2}\right]^{+}$. This ion is prepared and detected under the previous procedure. Ion 9 at $\mathrm{m} / \mathrm{z} 767.3$ fragments to yield the product ions $\mathbf{9 A}$ at $\mathrm{m} / \mathrm{z} 384.2$ and $\mathbf{1 A}-\mathrm{d}_{20}$ at $\mathrm{m} / \mathrm{z}$ 359.3 (Figure 3), which indicates that the phenyl of the product ion $\left[\mathrm{PPh}_{4}\right]^{+}$comes from the triphenylphosphine ligand. As a result, the finding from the SORICAD study of 9 provides a valuable clue about the phenyl shift between the palladium center and coordinated ligand via cleavage of the phosphorus-phenyl bond to give a palladium-phenyl intermediate.

\section{Fragmentation of Compounds 10, 11, and 12: Steric Effects}

When the position of substituents on the aromatic halides is changed from para to ortho, more fragmentation pathways are found in the SORI-CAD experiments. Ions $10\left[\left(o-\mathrm{CH}_{3}-\mathrm{C}_{6} \mathrm{H}_{4}\right) \mathrm{Pd}\left(\mathrm{PPh}_{3}\right)_{2}\right]^{+}, 11[(o-2,6-$ $\left.\left.\mathrm{Me}_{2} \mathrm{C}_{6} \mathrm{H}_{3}\right) \mathrm{Pd}\left(\mathrm{PPh}_{3}\right)_{2}\right]^{+}$, and $12\left[\left(\mathrm{C}_{10} \mathrm{H}_{7}\right) \mathrm{Pd}\left(\mathrm{PPh}_{3}\right)_{2}\right]^{+}$are studied by SORI-CAD experiments to investigate their fragmentation reactions. In comparison to the organopalladium ions 1-8, ions 10, 11, and 12 individually decompose to yield more fragment ions; the compositions and accurate masses of the fragment ions produced from these complexes are obtained using SORICAD in ESI-FTICR-MS. In addition to product ions $\left[\mathrm{PPh}_{3} \mathrm{Ar}\right]^{+}$and $\left[\mathrm{PPh}_{4}\right]^{+}$, Figure 4 a shows that ion $\mathbf{1 0}$ also yields product ions $10 \mathrm{~A}$ at $\mathrm{m} / \mathrm{z} 643.1$ and $10 \mathrm{~B}$ at $\mathrm{m} / \mathrm{z}$ 381.0 by loss of one molecule of benzene and one $\mathrm{PPh}_{3}$ ligand. Complex ions $\mathbf{1 1}$ and $\mathbf{1 2}$ display fragmentation chemistry similar to that of $\mathbf{1 0}$ ( Figure $4 \mathrm{~b}$ and c) [39].

Evidence from the SORI-CAD spectra of 10, 11, and

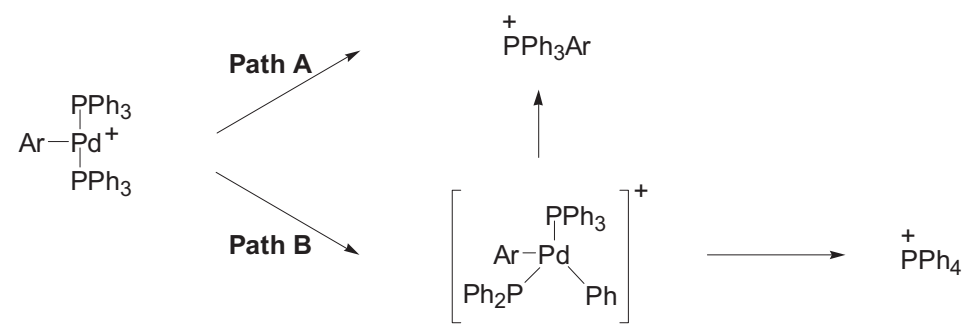

Scheme 2. Two proposed major fragmentation pathways for ions 1-7. Ion 8 fragments to produce only $\left[\mathrm{PPh}_{4}\right]^{+}$. 


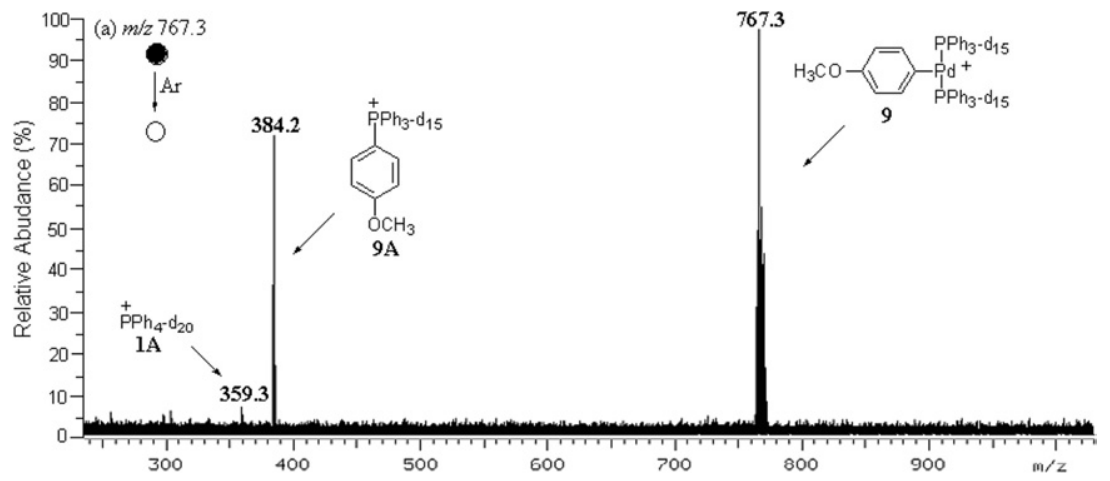

Figure 3. $\mathrm{ESI}(+)-\mathrm{SORI}-\mathrm{CAD}$ spectra for $\left[\left(p-\mathrm{OCH}_{3}-\mathrm{C}_{6} \mathrm{H}_{4}\right) \mathrm{Pd}\left(\mathrm{PPh}_{3}-\mathrm{d}_{15}\right)_{2}\right]^{+}$.
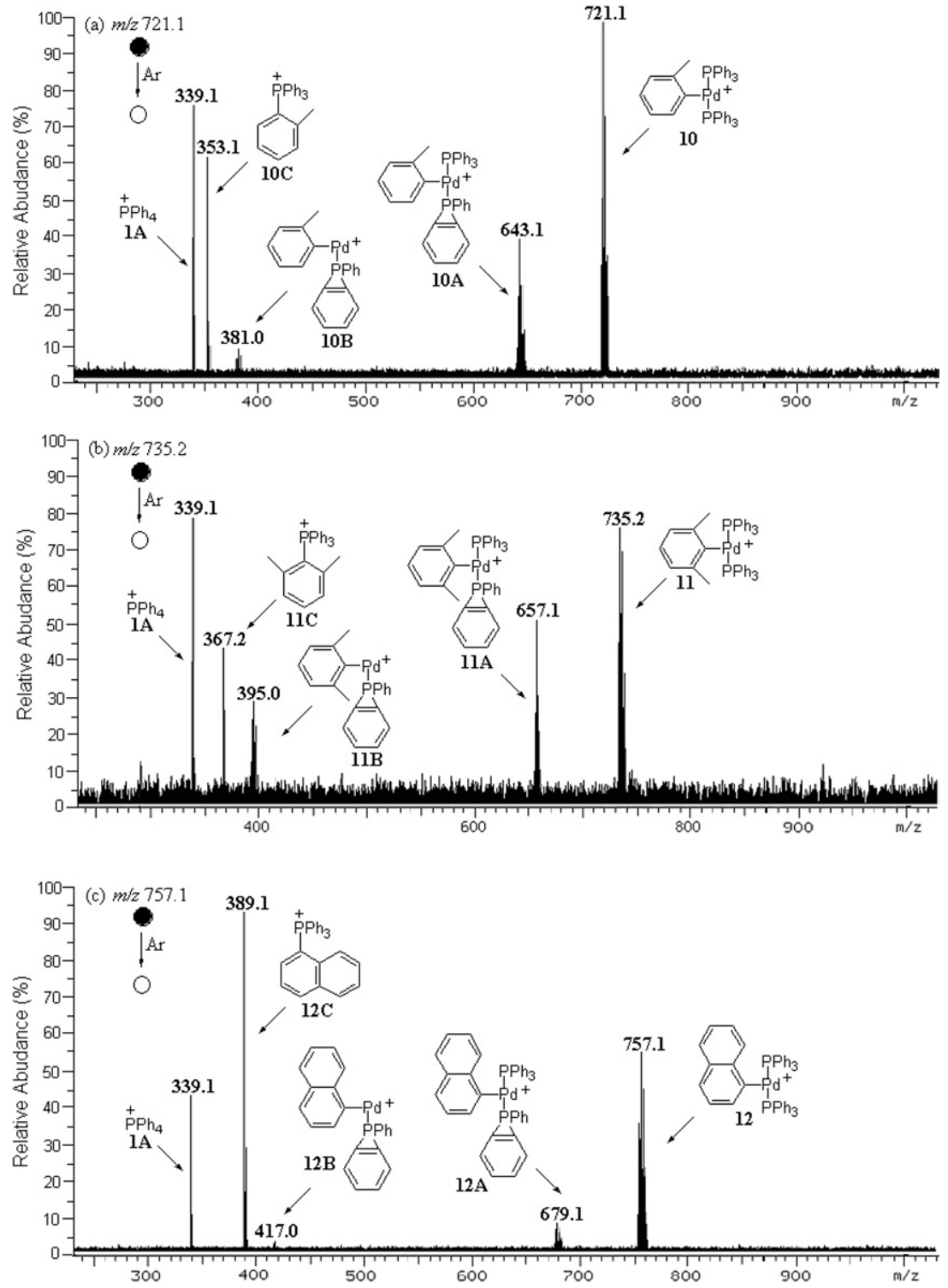

Figure 4. ESI(+)-SORI-CAD spectra for (a) $\left[\left(o-\mathrm{CH}_{3}-\mathrm{C}_{6} \mathrm{H}_{4}\right) \mathrm{Pd}\left(\mathrm{PPh}_{3}\right)_{2}\right]^{+}$, 10; (b) $\left[\left(o-2,6-\mathrm{Me}_{2}-\right.\right.$ $\left.\left.\mathrm{C}_{6} \mathrm{H}_{3}\right) \mathrm{Pd}\left(\mathrm{PPh}_{3}\right)_{2}\right]^{+}, \mathbf{1 1}$; and $(\mathbf{c})\left[\left(\mathrm{C}_{10} \mathrm{H}_{7}\right) \mathrm{Pd}\left(\mathrm{PPh}_{3}\right)_{2}\right]^{+}, 12$. 


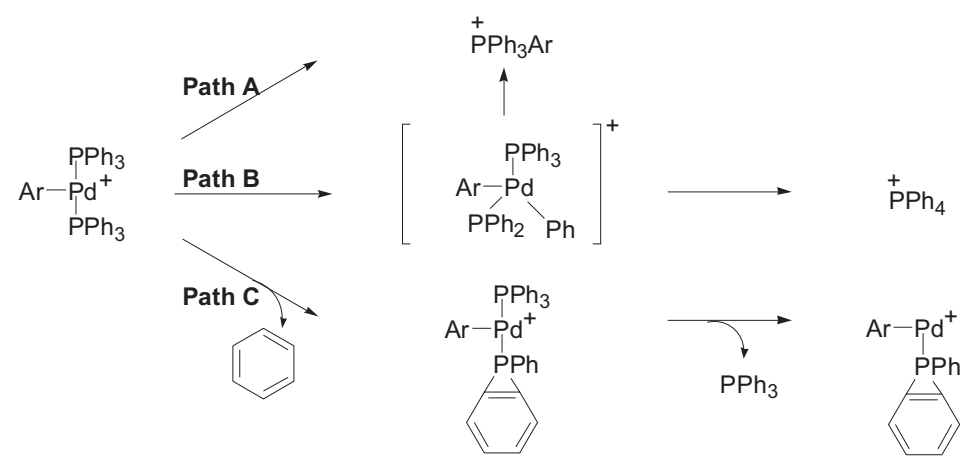

Scheme 3. Three proposed major fragmentation pathways for compounds 10, 11, and 12 .

12 suggests that there are three major fragmentation pathways for these three ions (Scheme 3). The first two pathways are similar to that of complex ions [ArPd$\left.\left(\mathrm{PPh}_{3}\right)_{2}\right]^{+} \quad\left(\mathrm{Ar}=p-\mathrm{OCH}_{3}-\mathrm{C}_{6} \mathrm{H}_{4}, p-\mathrm{CH}_{3}-\mathrm{C}_{6} \mathrm{H}_{4}, p-t \mathrm{Bu}-\right.$ $\mathrm{C}_{6} \mathrm{H}_{4}, p-\mathrm{NH}_{2}-\mathrm{C}_{6} \mathrm{H}_{4}, p-\mathrm{COCH}_{3}-\mathrm{C}_{6} \mathrm{H}_{4}$, and $\left.p-\mathrm{F}-\mathrm{C}_{6} \mathrm{H}_{4}\right)$. The third pathway begins with loss of one molecule of benzene to produce one product ion $\left[\mathrm{ArPd}\left(\mathrm{PPh}_{3}\right)\left(\mathrm{PPhC}_{6} \mathrm{H}_{4}\right)\right]^{+}\left(\mathrm{Ar}=o-\mathrm{CH}_{3}-\mathrm{C}_{6} \mathrm{H}_{4}, o-2,6-\mathrm{Me}_{2}-\right.$ $\mathrm{C}_{6} \mathrm{H}_{3}$, and $\mathrm{C}_{10} \mathrm{H}_{7}$ ), and then eliminates one $\mathrm{PPh}_{3}$ ligand to afford another product ion $\left[\mathrm{ArPPhC}_{6} \mathrm{H}_{4}\right]^{+}(\mathrm{Ar}=$ $o-\mathrm{CH}_{3}-\mathrm{C}_{6} \mathrm{H}_{4}, o-2,6-\mathrm{Me}_{2}-\mathrm{C}_{6} \mathrm{H}_{3}$, and $\mathrm{C}_{10} \mathrm{H}_{7}$ ). These results indicate that the steric effect of the aryl group influences the fragmentation pathways.

\section{Conclusions}

Mechanisms for fragmentation reactions of organopalladium ions $\left[\mathrm{ArPd}\left(\mathrm{PPh}_{3}\right)_{2}\right]^{+}$are elucidated in our work. The fragmentation reactions of complex ions 1-8 of electron-donating and electron-withdrawing aromatic iodides, except for $\mathbf{1}$ and $\mathbf{8}$, take place via two major pathways. Path A proceeds through reductive elimination of $\left[\mathrm{ArPd}\left(\mathrm{PPh}_{3}\right)_{2}\right]^{+}$to produce the product ion $\left[\mathrm{PPh}_{3} \mathrm{Ar}\right]^{+}$. Path $\mathrm{B}$ involves phenyl migration from the triphenylphosphine ligand to the palladium center to give a palladium-phenyl intermediate $\left[\mathrm{ArPd}\left(\mathrm{PPh}_{3}\right)\left(\mathrm{PPh}_{2}\right)(\mathrm{Ph})\right]^{+}$, and subsequent reductive elimination of the intermediate to yield the product ion 1A. Deuterium labeling experiments provide evidence for the phenyl shift between the palladium center and the coordinated ligand via cleavage of the phosphorus-phenyl bond; this process is also found to be enhanced by the electron-withdrawing substituents of aromatic halides and inhibited by electron-donating substituents of aromatic halides in the para position. The complex ions $\mathbf{1 0 - 1 2}$ display three competitive fragmentation pathways. Further studies in this area are underway in our laboratory.

\section{Acknowledgments}

The authors gratefully acknowledge the financial support by the National Nature Science Foundation of China (grant no. 20475059). Professor Shengming Ma (State Key Laboratory of Organometallic Chemistry, Shanghai Institute of Organic Chem- istry, P.R. China) is also gratefully acknowledged for reading the manuscript and for valuable suggestions.

\section{References}

1. Miyaura, N.; Suzuki, A. Palladium-Catalyzed Cross-Coupling Reactions of Organoboron Compounds. Chem. Rev. 1995, 95, 2457-2483.

2. Cabri, W.; Candiani, I. Recent Developments and New Perspectives in the Heck Reaction. Acc. Chem. Res. 1995, 28, $2-7$.

3. Tsuji, J.; Mandai, T. Palladium-Catalyzed Reactions of Propargylic Compounds in Organic Synthesis. Angew. Chem. Int. Ed. Engl. 1995, 34, 2589-2612.

4. Wolfe, J. P.; Wagaw, S.; Marcoux, J. F.; Buchwald, S. L. Rational Development of Practical Catalysts for Aromatic Carbon-Nitrogen Bond Formation. Acc. Chem. Res. 1998, 31, 805-818.

5. Stanforth, S. P. Catalytic Cross-Coupling Reactions in Biaryl Synthesis. Tetrahedron 1998, 54, 263-303.

6. Hartwig, J. F. Transition Metal Catalyzed Synthesis of Arylamines and Aryl Ethers from Aryl Halides and Triflates: Scope and Mechanism. Angew. Chem. Int. Ed. 1998, 37, 2046-2067.

7. Kong, K. C.; Cheng, C. H. Facile Aryl-Aryl Exchange Between the Palladium Center and Phosphine Ligands in Palladium(II) Complexes. J. Am. Chem. Soc. 1991, 113, 6313-6315.

8. O'Keefe, D. F.; Dannock, M. C.; Marcuccio, S. M. Palladium Catalyzed Coupling of Halobenzenes with Arylboronic Acids: Role of the Triphenylphosphine Ligand. Tetrahedron Lett. 1992, 33, 6679-6680.

9. Segelstein, B. E.; Butler, T. W.; Chenard, B. L. Equilibration of the Oxidative Addition Product of Tetrakis(Tripheny1Phosphine)Palladium and Electron-Rich Aryl Halides Leads to Product Scrambling in the Stille Reaction. J. Org. Chem. 1995, 60, 12-13.

10. Goodson, F. E.; Wallow, T. I.; Novak, B. M. Mechanistic Studies on the Aryl-Aryl Interchange Reaction of $\mathrm{ArPdL}_{2} \mathrm{I}$ (L = Triarylphosphine) Complexes. J. Am. Chem. Soc. 1997, 119, 12441-12453.

11. Flemming, J. P.; Pilon, M. C.; Borbulevitch, O. Y.; Antipin, M. Y.; Grushin, V. V. The trans-Influence of F, Cl, Br, and I Ligands in a Series of Square-Planar Pd(II) Complexes. Relative Affinities of Halide Anions for the Metal CentER in trans- $\left[\left(\mathrm{Ph}_{3} \mathrm{P}\right)_{2} \mathrm{Pd}(\mathrm{Ph}) \mathrm{X}\right]$. Inorg. Chim. Acta. 1998, 280, 87-98.

12. Grushin, V. V. Thermal Stability, Decomposition Paths, and $\mathrm{Ph} / \mathrm{Ph}$ Exchange Reactions of $\left[\left(\mathrm{Ph}_{3} \mathrm{P}\right)_{2} \mathrm{Pd}(\mathrm{Ph}) \mathrm{X}\right]\left(\mathrm{X}=\mathrm{I}, \mathrm{Br}, \mathrm{Cl}, \mathrm{F}\right.$, and $\left.\mathrm{HF}_{2}\right)$. Organometallics 2000, 19, 1888-1900.

13. Paul, F.; Patt, J.; Hartwig, J. F. Palladium-Catalyzed Formation of Carbon-Nitrogen Bonds. Reaction Intermediates and Catalyst Improvements in the Hetero Cross-Coupling of Aryl Halides and Tin Amides. J. Am. Chem. Soc. 1994, 116, 5969-5970.

14. Paul, F.; Patt, J.; Hartwig, J. F. Structural Characterization and Simple Synthesis of $\left\{\mathrm{Pd}\left[\mathrm{P}(\mathrm{o}-\mathrm{Tol})_{3}\right]_{2}\right\}$, Dimeric Palladium(II) Complexes Obtained by Oxidative Addition of Aryl Bromides, and Corresponding Monometallic Amine Complexes. Organometallics 1995, 14, 30303039 .

15. Garrou, P. E. Transition-Metal-Mediated Phosphorus-Carbon Bond Cleavage and Its Relevance to Homogeneous Catalyst Deactivation. Chem. Rev. 1985, 85, 171-185.

16. Nakazawa, H.; Matsuoka, Y.; Nakagawa, I.; Miyoshi, K. Catalytic Carbon-Phosphorus Bond Activation by Palladium Complexes. Decarbonylation and Metathesis reactions of $\alpha$-Ketophosphonates and Isolation of Aroyl(Phosphonate)Palladium Complexes as Intermediates. Organometallics 1992, 11, 1385-1392.

17. Ortiz, J. V.; Havlas, Z.; Hoffman, R. Alkyl Shifts Between Transition Metals and Coordinated Main Group Atoms. Helv. Chim. Acta. 1984, 67, $1-17$.

18. Reetz, M. T.; Lohmer, G.; Schwickardi, R. A New Catalyst System for the Heck Reaction of Unreactive Aryl Halides. Angew. Chem. Int. Ed. 1998, 37, 481-483. 
19. Hwang, L. K.; Na, Y.; Lee, J.; Do, Y.; Chang, S. Tetraarylphosphonium Halides as Arylating Reagents in Pd-Catalyzed Heck and Cross-Coupling Reactions. Angew. Chem. Int. Ed. 2005, 44, 6166-6169.

20. D'Agostino, C. A.; Traeger, J. C.; Colton, R. Electrospray Mass Spectrometry Applied to Inorganic and Organometallic Chemistry. Mass Spectrom. Rev. 1995, 14, 79-106.

21. Henderson, W.; Nicholson, B. K.; McCaffrey, L. J. Applications of Electrospray Mass Spectrometry in Organometallic Chemistry. Polyhedron 1998, 17, 4291-4313.

22. Traeger, J. C. Electrospray Mass Spectrometry of Organometallic Compounds. Int. J. Mass Spectrom. 2000, 200, 387-401.

23. Wee, S.; O'Hair, R. A. J.; McFadyen, W. D. Gas-Phase Ligand Loss and Ligand Substitution Reactions of Platinum (II) Complexes of Tridentate Nitrogen Donor Ligands. Rapid Commun. Mass Spectrom. 2004, 18, 1221-1226.

24. O'Hair, R. A. J.; Vrkic, A. K.; James, P. F. Gas-Phase Synthesis and Reactivity of the Organomagnesates $\left[\mathrm{CH}_{3} \mathrm{MgL}_{2}\right]^{-}(\mathrm{L}=\mathrm{Cl}$ and $\mathrm{O}_{2} \mathrm{CCH}_{3}$ ): From Ligand Effects to Catalysis. J. Am. Chem. Soc. 2004, 126, 12173-12183.

25. Bhaskar, G.; Chary, M. A.; Kumar, M. K.; Syamasundar, K.; Vairamani, M.; Prabhaker, S. Electrospray Ionization Studies of Transition-Metal Complexes of 2-Acetylbenzimidazole Thiosemicarbazone Using Collision-Induced Dissociation and Ion-Molecule Reactions. Rapid Commun. Mass Spectrom. 2005, 19, 1536-1544

26. Bach, S. B. H.; Sepeda, T. G.; Merrill, G. N.; Walmsley, J. A. Complexes of Dibromo(Ethylenediamine)-Palladium(II) Observed from Aqueous Solutions by Electrospray Mass Spectrometry. J. Am. Soc. Mass Spectrom. 2005, 16, 1461-1469.

27. Qian, R.; Guo, H.; Liao, Y.; Guo, Y.; Ma, S. Probing the Mechanism of the Palladium-Catalyzed Addition of Organoboronic Acids to Allenes in the Presence of AcOH by ESI-FTMS. Angew. Chem. Int. Ed. 2005, 44, 4771-4774.

28. Guo, H.; Qian, R.; Liao, Y.; Ma, S.; Guo, Y. ESI-MS Studies on the Mechanism of Pd(0)-Catalyzed Three-Component Tandem Double
Addition-Cyclization Reaction. J. Am. Chem. Soc. 2005, 127, 13060-13064.

29. Qian, R.; Guo, H.; Liao, Y.; Wang, H.; Zhang, X.; Guo, Y. Studies of Gas-Phase Fragmentation Reactions of $\left[\mathrm{Pd}\left(\mathrm{PPh}_{3}\right)_{2}(\mathrm{OCOR})\right]^{+}$by Electron Ionization Fourier Transform Ion Cyclotron Resonance Mass Spectrometry. Rapid Commun. Mass Spectrom. 2006, 20, 589-594.

30. Fitton, P.; Rick, E. A. The Addition of Aryl Halides to Tetrakis(Triphenylphosphine)Palladium. J. Organometal. Chem. 1971, 28, 287-291.

31. Coulson, D. R. Tetrakis(Triphenylphosphine)Palladium. Inorg. Synth. 1972, 13, 121-124.

32. Yamane, T.; Kikukawa, K.; Takagi, M.; Matsuda, T. Reaction of Coordinated Phosphines-II Arylation of Substituted Olifens by Palladium(II) Acetate and Triarylphosphine. Tetrahedron 1973, 29, 955-962.

33. Gillie, A.; Stille, J. K. Mechanism of 1,1-Reductive Elimination from Palladium. J. Am. Chem. Soc. 1980, 102, 4933-4941.

34. Abatjogiou, A. G.; Bryant, D. R. Aryl Group Interchange Between Triarylphosphines Catalyzed by Group 8 Transition Metals. Organometallics 1984, 3, 932-934.

35. Abatjogiou, A. G.; Bryant, D. R. Mechanism of Rhodium-Promoted Triphenylphosphine Reactions in Hydroformylation Processes. Organometallics 1984, 3, 923-926.

36. Sakamoto, M.; Shimizu, I.; Yamamoto, A. Palladium-Catalyzed Cleavage of $\mathrm{P}-\mathrm{C}$ bonds in Quaternary Phosphonium Salts and Its Applications to Organic Synthesis. Chem. Lett. 1995, 1101-1102.

37. Lewin, M.; Ainzenshtat, Z.; Blum, J. Formation of Diaryls by Thermal Decomposition of Rhodium(I) Triarylphosphine Complexes. J. Organomet. Chem. 1980, 184, 255-261.

38. Gole, A. B. Palladium(II) Catalyzed Cleavage of Aryl-Phosphorus Groups of Tertiary Arylphosphine. Inorg. Chim. Acta. 1984, 84, L25-L27.

39. Sabino, A. A. Machado, A. H. L. Correia, C. R. D. Eberlin, M. N. Probing the Mechanism of the Heck Reaction with Arene Diazonium Salts by Electrospray Mass and Tandem Mass Spectrometry. Angew. Chem. Int. Ed. 2004, 43, 2514-2518. 